\title{
Mais branco do que preto na ditadura militar brasileira: a Democracia Corinthiana, o sindicalismo, a rebeldia e o rock and roll
}

\author{
Whiter than Black in Brazilian Military Dictatorship: Corinthian \\ Democracy, Syndicalism, Rebellion and Rock and Roll
}

\author{
Augusto Sarmento-Pantoja \\ Universidade Federal do Pará/Brasil \\ Doutor da Teoria e História da Literatura, UNICAMP \\ augustos@ufpa.br
}

\begin{abstract}
RESUMO: Este estudo discutirá o documentário Democracia em preto e branco (2014), de Pedro Asbeg, e suas relações entre política, futebol e música. 0 documentário, comemorativo dos 30 anos do fim do movimento Democracia Corinthiana (1982-1984), é uma especial homenagem ao Dr. Sócrates, a figura mais emblemática do movimento político-esportivo, falecido em 2011. 0 filme traça seu argumento na esperança de compreender como o movimento Democracia Corinthiana sai dos campos de futebol e se transforma na ponte política para engrossar a massa de protestos a favor da democracia e pelas eleições diretas para presidente da república no Brasil. Entre as contribuições do filme para o debate entre política e futebol temos o destaque para o lateral esquerdo Wladimir, que seria, na ocasião, o principal fomentador de um projeto sindical entre os jogadores de futebol, que entretanto ficou legado a condição de coadjuvante de Sócrates e Casagrande. 0 primeiro marcado como mártir do movimento e o segundo pela associação de sua imagem às noções de rebeldia rock ' $n$ ' roll, representante da geração 1980. Nossa reflexão, busca discutir as estratégias de resistência e autoritarismo para que o movimento, tanto da democracia quanto das diretas, se tornasse mais branco do que preto. Colaboram para esse estudo reflexões de Norberto Bobbio, Walter Benjamin, Theodor Adorno, Alfredo Bosi e Elcio Cornelsen.
\end{abstract}

PALAVRAS-CHAVE: Cinema; Democracia Corinthiana; Diretas Já; Futebol; Música.

ABSTRACT: This study discusses the documentary Democracia em preto e branco (2014) by Pedro Asbeg and its relationship between politics, football and music. The documentary commemorates the 30th anniversary of the end of the Corinthian Democracy movement (19821984) and is a special tribute to doctor Sócrates, the most symbolic figure of the political-sportive movement, who died in 2011. The film sets out its argument hoping to understand how the Corinthian Democracy movement leaves the football fields and becomes the political bridge to thicken the mass of protests in favor of democracy and the direct elections for president of the republic in Brazil. Among the contributions of films to the debate on politics and football, we highlight the left-back Wladimir, who would be the main promotor of a trade union policy among football players, who was relegated to a supporting role for Sócrates and Casagrande in the movement. The first marked as martyr to the movement and the second by the association of his image with notions of rebellion and rock ' $n$ ' roll, as a representative of the generation the 80's. Our reflection seeks to discuss how strategies of resistance and authoritarianism made the democratic and direct vote movement turn whiter than black. Inspiration for this study comes from Norberto Bobbio, Walter Benjamin, Theodor Adorno, Alfredo Bosi and Elcio Cornelsen.

KEYwoRDS: Cinema; Corinthian Democracy; Diretas Já; Football; Music. 


\title{
Paixão em Branco e Preto
}

\author{
Por que será que eu gosto de sofrer? \\ Vai ver que agora eu dei pra masoquista \\ Meu amor branco e preto \\ Às vezes me deixou na mão \\ Mas eu gosto de você \\ Já não me importa a sua ingratidão \\ Sofro, mas continuo a te adorar \\ Corinthians meu amor! \\ Corinthians! \\ "Amor branco e preto", Rita Lee.
}

Para muitos, torcer é sofrer! Formas sinônimas em diversos gramados, em especial, no futebol. Principalmente quando falamos da história de clubes com elevado número de torcedores, os chamados "clubes de massa". Nesses clubes, as grandes torcidas exigem performances de alto nível, tendo como objetivo a conquista de títulos. Mas, como todo esporte, não há espaço para vários vencedores, pelo contrário, temos sempre clubes que não conseguem nenhum título, por anos a fio. Daí a sensação experimentada por grande parte dos torcedores de que o seu clube o "deixou na mão", como na canção de Rita Lee, que produz esse sentimento de um melancólico vazio: espécie de saudade do título não conquistado, muito comum entre os torcedores, já que nem sempre eles comemoram, pois, no Brasil, há grande alternância de campeões. Contraditoriamente, a decepção pela derrota aumenta a paixão, em sua dupla acepção, uma vez que remete ao mesmo tempo ao prazer e ao sofrimento.

Etimologicamente, entre as diversas acepções que possui, é possível simplificar o vocábulo "paixão" em um dístico antagônico: predileção/martírio, como causa e consequência das experiências passionais. A predileção leva ao martírio! Amar um clube permite que o torcedor, em nome de sua predileção, sofra pelo clube, sem considerar o sofrimento um problema. Em muitos casos, os termos que formam o dístico chegam a ser considerados homônimos, ao produzir uma relação passional entre torcedores, atletas e clubes, na medida em que o clube deixa a todos "na mão". Apesar do âmbito pessoal, esse sentimento está bastante ligado ao que Elcio Cornelsen salienta sobre a constituição do sentimento de nação 
em grandes eventos esportivos. Mesmo que o crítico não se refira a clubes e sim a seleções de países, ao analisar a Copa do Mundo na Alemanha, vemos essa mesma estratégia vivida no caso dos clubes de futebol, já que os clubes também possuem alcunhas referenciais que espelham a ideia de coletivo nacional, tais como Nação Corinthiana (Timão), por exemplo, assim:

[a]pelos dessa natureza suprimem distinções sociais e políticas e constroem um sentimento de unidade. Sobretudo em tempos de insegurança e de transformação econômica, política e social, cresce a identificação com a própria Nação. Desse modo, Nação e identidade nacional tornam-se elementos de vínculo à sociedade em transformação. ${ }^{1}$

No princípio dos anos 1980 as transformações tanto no Corinthians, quanto no Brasil, estavam a caminho e se faziam paralelas: as da Nação Corinthiana marcadas pelo desejo de afirmação enquanto clube nacional, e, as da nação brasileira, envoltas pelo desejo de realização de eleições diretas para presidente e, consequentemente, a afirmação democrática, após o hiato da ditadura. Por isso, entendemos que a melhor leitura sobre esse momento histórico brasileiro se refere ao desejo de liberdade, associada à promessa de abertura para a democracia e de anistia política.

Após esse breve aquecimento, passemos ao "pontapé inicial" do jogo, pois os anos de 1980 revelam, portanto, que esse desejo de transformação, sobretudo político, também se apresenta no futebol. É interessante notar que o Brasil, após o tricampeonato mundial de futebol (1958/1962/1970) e dos louros da era Pelé, com o Santos, começa a construir um movimento para a afirmação dos clubes de massa do eixo Rio-São Paulo. Pois, até essa altura, os dois mais conhecidos clubes brasileiros, Flamengo, no Rio de Janeiro, e, Corinthians, em São Paulo, não detinham conquistas nacionais, apesar de serem considerados clubes com visibilidade e grandes potências no futebol, tanto que o Flamengo ganha seu primeiro título nacional em 1980, na chamada era Zico, mas o Corinthians chega à primeira conquista apenas em 1990.

No caso do Sport Club Corinthians Paulista, ou, simplesmente, Corinthians ou Timão, os anos 1980 foram significativos para a afirmação do vínculo do clube com a

\footnotetext{
${ }^{1}$ CORNELSEN. Sentimento e política no futebol alemão: construção da nação em 1990 e 2006, p. 76.
} 
torcida e para abrir o caminho para a concretização do projeto de obtenção do tão sonhado título nacional. Esse início vai se dar com jogadores, como Sócrates, Wladimir, Casagrande, Zenon e Biro-Biro, que ganharam grande reconhecimento popular, em especial, por conta de suas atuações no campo, mas também na mídia, já que há uma intensa interlocução desses jogadores com a torcida e com a crítica esportiva.

Nesta época, os torcedores viviam a experiência daquele dístico antagônico da paixão, de que falamos anteriormente, já que a campanha do clube no campeonato nacional de 1981 (Taça de Ouro) fora desastrosa, culminando no rebaixamento para a $2^{\mathrm{a}}$ divisão (Taça de Prata). Entretanto, o início da década propunha uma mudança de rumos para o Timão, mobilizado pela euforia da quebra do jejum de 22 anos sem títulos (1955-1976), vencendo o campeonato paulista de 1977, sob o julgo daquilo do que ficou conhecido como a "ditadura corintiana", 2 ao comando do Presidente Vicente Matheus, como bem destaca a narração em voz off de Rita Lee, no documentário Democracia em preto e branco, objeto desta análise:

No Distrito Federal o General Figueiredo, temido chefe do SNI, recebia a faixa presidencial enquanto que no Corinthians, outro presidente, driblava o estatuto e reforçava sua própria ditadura no Parque São Jorge. Naquele tempo o timão estava muito por baixo. Vicente Matheus era um tiozinho tão interessado na alternância de poder quanto qualquer um dos milicos de plantão. ${ }^{3}$

Ser campeão, depois de tanto tempo, fortaleceu ainda mais Vicente Matheus, proporcionando o anseio de se perpetuar no poder, ao formular a estratégia de se candidatar ao vicenato na chapa de Waldemar Pires. Para a imprensa, esta era uma jogada para driblar o estatuto do clube, pois, mesmo na condição de vice Matheus poderia mandar no Parque São Jorge. Porém, após três meses de mandato, o presidente Waldemar Pires afasta Vicente Matheus do cargo e assume as regras do jogo, e, com ele, os efeitos do rebaixamento para a segunda divisão. A fim de fazer o combate fora do campo, com intuito de arrumar a casa, Pires contrata e traz para o jogo o sociólogo Adilson Monteiro Alves, que faz uma reviravolta no clube.

\footnotetext{
${ }^{2}$ A alcunha se deu por conta da constante associação dos dirigentes do Sport Club Corinthians Paulista com os generais da ditadura brasileira. Além disso, Vicente Matheus, presidente do clube, se perpetuava no poder como se estivesse implantando a sua própria ditadura.

${ }^{3}$ ASBEG. Democracia em preto e branco, 5'57"-6'27".
} 
Reconhecido como um jovem dirigente socialista, na primeira reunião com o elenco, no final de 1981, inicia uma filosofia que será abraçada pelos jogadores, técnico e demais membros do coletivo. Alves propõe associar o diálogo e a participação de todos os jogadores no direcionamento do time. A propósito dessa mudança vejamos o depoimento do próprio Alves:

Acho que futebol não é desse jeito, mas eu não sei como é! E gostaria que a gente descobrisse juntos uma maneira de fazer futebol, de jogar futebol, de viver futebol e principalmente de participar da sociedade, participar do momento que está se vivendo, o país está em um momento... era final de 81, muito duro e nós estamos e vocês do futebol estão assistindo, nenhuma participação! Nenhuma opinião! Sendo que qualquer coisa que vocês digam é muito importante. ${ }^{4}$

Essa postura que valoriza a voz do atleta tomou conta do dia a dia do clube, fazendo com que o jornalista esportivo Juca Kfouri nomeasse o fenômeno administrativo de "democracia de corintianos". Uma alcunha posteriormente reformulada pelo publicitário Washington Olivetto, que passa a denominá-la de "Democracia Corinthiana”. Olivetto foi outra contratação fundamental para o clube, já que ele fora convocado para liderar e organizar, por meio do marketing, essa mudança no Corinthians. Além de se compor como base de gestão administrativa a Democracia Corinthiana torna-se nas mãos de Olivetto uma nova filosofia, portadora do ambicioso desejo de projetar o clube como campeão nacional, o que resulta em uma verdadeira explosão popular, pois até então a "fiel"5 nunca tinha levantado o caneco de nenhum campeonato brasileiro.

A "fiel"6 nunca tinha levantado o caneco de nenhum campeonato brasileiro, mesmo sendo um dos maiores vencedores da história do campeonato paulista, ainda que tenha antes amargado 22 anos de jejum, 0 Corinthians recupera a condição de maior vencedor paulista com a implantação da Democracia Corinthiana, ${ }^{7}$ que durou

\footnotetext{
${ }^{4}$ ASBEG. Democracia em preto e branco, 13'05"-13'45".

${ }^{5}$ Alcunha dada à torcida do Corinthians, proporcionada pelo longo jejum de título no período de 1955-1976, já que se mantinha fiel ao clube, mesmo com tanto tempo sem ser campeão.

${ }^{6}$ Alcunha dada à torcida do Corinthians, proporcionada pelo longo jejum de título no período de 1955-1976, já que se mantinha fiel ao clube, mesmo com tanto tempo sem ser campeão.

7 A experiência da Democracia Corintiana também ganhou destaque em dois outros documentários: Ser campeão é detalhe - democracia corinthiana (2011), de Gustavo Forti Leitão e Caetano Tola Biasi, filme que destaca o movimento como parte do diferencial do clube em relação aos demais; e Todo poderoso: o filme - 100 anos de Timão (2010), de Ricardo Ainda e André Garolli, comemorativo do centenário do clube, faz uma recuperação histórica
} 
apenas duas temporadas, mas foi o suficiente para dar ao clube a visibilidade necessária para sair da esfera regional e se tornar, em pouquíssimo tempo, um dos maiores campeões entre clubes nacionais.

Para além do aspecto midiático, o modelo de gestão do clube, agora baseada na democracia, que faltava ao país e ao futebol, ganha força com os títulos de 1982 e 1983, mas se afunda em 1984, quando o título não vem. Àquela altura, com o insucesso de 1984, passa a pairar uma descrença em relação ao modelo. Contudo, certamente o trabalho construído naqueles anos foi muito produtivo, entretanto, não teria sido o suficiente para derrubar a ditadura no futebol, fincada até hoje nas mãos dos dirigentes e quiçá, na dos treinadores, isso porque a cultura futebolística no Brasil nos mostrou ao longo dos anos "que a corda sempre arrebenta nas mãos dos mais fracos", neste caso nas mãos dos treinadores, daí observarmos a dança das cadeiras de técnicos, que são demitidos sumariamente, em alguns casos sem justificativa alguma.

A instauração da democracia no futebol como modelo de gestão, algo que até então nunca havia sido experimentado e que não voltou a ser praticado, infelizmente, não reverberou nos outros clubes, nem da cidade de São Paulo, nem do resto do Brasil.

Com certeza, a ditadura civil-militar que vigorava procurou se certificar de que a Democracia Corinthiana não se alastrasse por outros clubes. Para a repressão seria perigoso que o modelo reverberasse. 0 filme não toca diretamente neste tema, mas apresenta alguns depoimentos em que transparece a complexidade do que fora o movimento, aonde para alguns entrevistados do filme, a experiência teria sido boa e se mostravam eufóricos com a experiência democrática, para outros a experiência tinha sido frustrante pelo fato da democracia não ter vingado, nem no futebol. Por isso, vinha a questão: Se a democracia era boa para o futebol porque não continuou?

A resposta não é fácil, mas sabemos que no futebol, como em vários outros setores econômicos, "manda quem pode e obedece quem tem juízo", já dizia o ditado popular. Parece-nos que o clube, nesses anos de democracia, por somente se manter o domínio estadual, o modelo, apesar de bem-sucedido, não ganhou força suficiente para reverberar em outros clubes, como os já campões nacionais Flamengo, Santos, 
Vasco da Gama, Palmeiras, Fluminense, São Paulo, Grêmio e Internacional, Atlético Mineiro e Cruzeiro, ainda mais em clubes de menor expressividade.

Essa questão nos faz pensar novamente no paralelo entre a Nação Corinthiana e a nação brasileira, no âmbito de suas relações com a democracia. No fim das contas, parece que o povo (torcida) foi mais uma vez manipulado pelas estruturas de controle ditatoriais, uma vez que muita coisa é decidida no tapetão. Imaginem o que teria acontecido se a emenda constitucional Dante de Oliveira (PEC 5/02/03/1983) tivesse sido aprovada em 1984? Certamente não teríamos a farsa que se deu nas eleições de 1985, quando achávamos que realmente vivíamos em um regime democrático, por ter um presidente não militar, mesmo que este estivesse alinhado a eles. Vamos pedir um tempo técnico, para falarmos um pouco de como estava disposto aquele jogo político da época.

Observemos que para as eleições indiretas tínhamos uma configuração incomum, pois o presidente João Figueiredo opta por não realizar a articulação necessária para a sucessão presidencial, o que demonstraria a inclinação política do Estado em deixar de ser governado por um militar. Entretanto não passava de uma estratégia do projeto de abertura política da ditadura, que passaria a impressão que o novo governo seria civil, contudo, com um forte direcionamento para as ideologias conservadoras.

Como efeito disso, tivemos uma cena eleitoral favorável ao regime militar, pois nas eleições de 1985, tivemos dois civis concorrendo à presidência, Paulo Maluf que representava, mesmo não sendo militar, a continuidade do regime e Tancredo Neves, representante de uma oposição moderada e conservadora, que na esteira do movimento Diretas Já! ganha força como parte das vozes da oligarquia mineira, articulada com uma ala dissidente dos apoiadores do regime militar, que agora se apresentavam como oposicionistas e compunham a chapa composta por Tancredo Neves e José Sarney, um vice que sempre fez parte da base de apoio à ditadura. Curiosa e ironicamente, o "dissidente" Sarney foi empossado como presidente, diante da nebulosa doença e morte de Tancredo Neves. Parece que a mala tinha sido trazida para o campo. ${ }^{8}$

\footnotetext{
${ }^{8}$ Uma alusão à corrupção em relação à compra de resultados no futebol, constantemente relacionado à figura de um dirigente e sua mala com dinheiro responsável por comprar os
} 
O movimento Democracia Corinthiana esteve rodeado de perto pelo governo ditatorial e pelo conservadorismo que impedia o desenvolvimento de práticas democráticas no futebol.

E, por falar em democracia, vemos que o conceito perpassa por transformações ideológicas, mas acaba fundamentado em bases aparentadas ao poder autoritário, vejamos como é complexo o conceito de Democracia nas palavras de Norberto Bobbio:

$\mathrm{Na}$ teoria contemporânea da Democracia confluem três grandes tradições do pensamento político: a) a teoria clássica, divulgada como teoria aristotélica, das três formas de Governo, segundo a qual a Democracia, como Governo do povo, de todos os cidadãos, ou seja, de todos aqueles que gozam dos direitos de cidadania, se distingue da monarquia, como Governo de um só, e da aristocracia, como Governo de poucos; b) a teoria medieval, de origem romana, apoiada na soberania popular, na base da qual há a contraposição de uma concepção ascendente a uma concepção descendente da soberania conforme o poder supremo deriva do povo e se torna representativo ou deriva do príncipe e se transmite por delegação do superior para o inferior; c) a teoria moderna, conhecida como teoria de Maquiavel, nascida com o Estado moderno na forma das grandes monarquias, segundo a qual as formas históricas de Governo são essencialmente duas: a monarquia e a república, e a antiga Democracia nada mais é que uma forma de república (a outra é a aristocracia), onde se origina o intercâmbio característico do período pré-revolucionário entre ideais democráticos e ideais republicanos e o Governo genuinamente popular é chamado, em vez de Democracia, de república. O problema da Democracia, das suas características, de sua importância ou desimportância é, como se vê, antigo. Tão antigo quanto a reflexão sobre as coisas da política, tendo sido reproposto e reformulado em todas as épocas. De tal maneira isto é verdade, que um exame do debate contemporâneo em torno do conceito e do valor da Democracia não pode prescindir de uma referência, ainda que rápida, à tradição. ${ }^{9}$

Ao pensar sobre as análises de Bobbio, temos que nos questionar sobre sua formulação, pois, no caso da democracia clássica o conflito conceitual está na construção da ideia de cidadão, pois para a cultura clássica, nem todos os indivíduos são considerados cidadãos, o que faz com que exista uma elite, formando um grupo social que detêm os direitos políticos, ou seja, há um grupo

resultados dos jogos. Neste caso associamos o resultado das eleições e a posse do vice a uma espécie de resultado comprado, ou seja o candidato da ditadura perdeu, mas assumiu o vice, também alinhado às ideologias do regime civil-militar que vigorou por vinte e um anos no Brasil. ${ }_{9}^{9}$ BOBBIO. Dicionário de Política, p. 319b-320a. 
que goza das benesses da cidadania e autoritariamente pode decidir e ser reconhecido, votar e ser votado. Dessa forma, ter um governo do povo, também está relacionado ao alijamento de inúmeros indivíduos, pertencente ao povo, mas não reconhecidos como parte dele, entre eles se destacam as mulheres, que não possuem representatividade na Democracia Clássica e ficam alijadas por séculos e séculos desse direito. Entretanto, destaca-se o fato de nesta forma de democracia termos a escolha (voto direto) emanada dos cidadãos (povo).

De outro modo, na teoria medieval a escolha está vinculada ao poder divino e a manutenção das castas sociais fixadas pelo regime de suserania e vassalagem, diretamente ligado à ideia de soberania de um rei e de uma família nobre, aqui as mulheres ficam alijadas também, mas alijados são também todos os que não pertencerem às castas superiores, dos escolhidos.

Por fim vemos a teoria moderna, quando analisada em função da noção de Democracia, vinculada à constituição dos regimes Republicanos, em oposição ao Absolutismo (Aristocrático). Sabemos que, em campo, a democracia parece bem assentada no que Bobbio chama de "Governo genuinamente popular", como parte da Democracia (República), mas fica notório que há uma crítica eminente ao articular o passado Clássico ao Moderno, quando um se alimenta do outro, já que o poder continua nas mãos de elites "escolhidas", agora, em teoria essa escolha é feita pelo povo, mas em geral chegam ao poder aqueles oriundos de famílias aristocráticas ou burguesas.

Após o tempo técnico, voltamos ao campo de olhos abertos, como os do VAR (Video Assistant Referee), como árbitro assistente de vídeo. Ao assistirmos ao documentário, compreendemos bem a articulação entre futebol e política, desde o uso de determinadas estratégias formais, como a voz off, até a intersecção com as cenas históricas, sem deixar de lado a trilha sonora, na qual o cineasta dá grande atenção e resolve acrescentar um terceiro vértice, a música como parte da reflexão sobre a necessidade de fomentar a liberdade e que durante toda a ditadura civil-militar 
brasileira teve papel importante na luta contra o autoritarismo, em especial nos anos de 1960 e 1970, a cargo da Música Popular Brasileira (MPB) e da Tropicália. ${ }^{10}$

Nos anos de 1980, esse espaço de protesto estava relativamente "vago" e aos poucos foi sendo tomado por um movimento que inicia ainda no final da década de 1970 e ganhará maior intensidade na década seguinte com o rock 80. Esse coletivo musical, produz canções reflexivas acerca da perplexidade diante dos problemas sociais e políticos brasileiros, o silencio instalado diante do aniquilamento dos movimentos de resistência e a letargia produzida pela censura à cultura brasileira. $\mathrm{Na}$ esteira das ponderações de Theodor Adorno, em seu livro Teoria Estética, vemos que nos anos de abertura há necessidade de estranhar o mundo por meio da arte, pois "[a] estranheza ao mundo é um momento da arte; quem não percebe a arte como estranha ao mundo de nenhum modo a percebe", 11 esse estranhamento pode ser percebido na arte dos anos 1980, no Brasil, principalmente ao direcionarmos o olhar para a música produzida no âmbito da resistência e à falta de liberdade de expressão, notórias naqueles tempos. Alfredo Bosi colabora com essa posição, ao evocar Benedetto Croce, para considerar que a

experiência dos artistas e o seu testemunho dizem, em geral, que a arte não é uma atividade que nasça da força de vontade. Esta vem depois. A arte teria a ver primariamente com as potências do conhecimento: a intuição, a imaginação, a percepção e a memória. ${ }^{12}$

O filme Democracia em preto e branco propõe essa articulação, associado ao um movimento de propagação do rock nacional, que revelou dezenas de bandas, preocupadas em fazer rock em português e usar suas músicas para fazer resistência. Para além dessa nova onda de resistência na música, vimos que o futebol também criou espaço para fazer resistência política por meio da Democracia Corinthiana, articulando-se a onda do rock 80 e da Diretas Já!, como se um nutrisse o outro. Por isso, no documentário, temos a impressão de que os movimentos ocorrem ao mesmo tempo, contudo é importante ressaltar que a maioria das músicas que compõem a trilha sonora do filme, e que pertencem ao

${ }^{10}$ Com a intensa perseguição do regime ditatorial, vimos artistas como Chico Buarque, Caetano Veloso, Gilberto Gil, Geraldo Vandré, entre outros, terem que pendurar suas chuteiras, fugir do Brasil e viver no exílio.

${ }_{11}$ ADORNO. Teoria Estética, p. 208.

${ }^{12}$ BOSI. Narrativa e resistência, p. 11. 
Rock 80, só foi lançada depois de 1985, quando a Democracia Corinthiana já havia entrado em declínio. ${ }^{13}$ Ora bolas, nem todos os lances terminam em gol!

Chamo atenção para esse fato, porque o rock 80 , sem dúvida teve importância emblemática para compreendermos os novos tempos democráticos, mas não embalaram o período da Democracia Corinthiana, podendo até entendê-las como inspiradas por uma necessidade de liberdade e de narrar a realidade violenta e autoritária que permanecia no Brasil, mesmo depois de decretado o fim da ditadura, pelo menos entre os políticos, pois Sarney, para mim, fazia parte do esquema e foi aquela substituição aos 45 minutos do segundo tempo, para garantir o resultado.

O filme inicia ao som de "Núcleo base", da banda Ira!, lançado no álbum Mudança de comportamento, de 1985, com essa música o documentário apresenta o desejo dos jovens roqueiros de fazer um novo debate por meio de letras que trazem à tona a necessidade de mudança, a instauração da democracia e a deflagração de um fim efetivo dos governos civil-militares e do regime ditatorial. Vejamos as passagens:

Eu tentei fugir, não queria me alistar Eu quero lutar, mas não com esta farda Eu tentei fugir, não queria me alistar Eu quero lutar, mas não com esta farda

E já está ficando tarde e eu estou muito cansado Minha mente está tão cheia e eu estou me transbordando Você pensa que eu sou tolo, mas eu estou só te olhando lá Lala Lala Lala.

Eu tentei fugir não queria me alistar Eu quero lutar, mas não com essa farda Eu tentei fugir não queria me alistar Eu quero lutar, mas não com essa farda Mas não com essa farda, mas não com essa farda Mas não com essa farda, mas não... ${ }^{14}$

Identificamos a clara sensação de derrocada da ditadura, pois as fardas já não são o ideal da juventude, que constantemente são acusados de serem tolos e inconsequentes, mas as mentes dos jovens dos anos de 1980, que viveram a

${ }^{13}$ O documentário não deixa dúvidas de que movimento musical, surfou nas ondas da abertura política, quando já tínhamos outro cenário, em que já sabíamos que teríamos um presidente civil e eleições indiretas, o que mudaria um pouco o cenário construído nas décadas anteriores. ${ }^{14}$ IRA!. Núcleo base, 1985. 
infância sob o julgo dos Atos Institucionais, do controle e da censura, estão cheias de ideias e querem mudança. 0 filme busca associar a voz da Democracia Corinthiana com as vozes de protesto do rock and roll nacional, pensado a olhar para os problemas brasileiros, que com a anistia, passam a sofrer menos com a censura.

As digressões e progressões temporais no filme são constantes, mas, apesar desses movimentos de vai e volta, temos a ideia de contínuo temporal, graças à narração de Rita Lee, que inicia com a chegada da "democracia" no Brasil, ainda na proclamação da República, em 1889 e aos poucos chega à ditadura de 1964. Nesses 130 anos, “a democracia funcionou, mas deu uma parada para o almoço e só voltou depois da segunda guerra, mas aí chegou 1964 e começou a mais longa noite da democracia brasileira". 15 Somados os períodos em que o Brasil foi realmente democrático não temos nem metade desse tempo, isso se relativizarmos o que é a democracia, pois no fundo vivemos democracias sob o julgo autoritário da política do café com leite, com intensas alternâncias políticas entre as elites mineiras e paulistanas, tendo os cariocas sediando o teatro do poder e articulando as apostas e os bolões.

Ao som de "Vote em mim" (1982), Rita Lee chama ao palco do Ibirapuera os três exponenciais nomes da Democracia Corinthiana, Sócrates, Casagrande e Wladimir, que juntos festejavam a liberdade de expressão, que durante 15 anos (1964-1979) não passava de utopia, e que no documentário ganha o protagonismo no movimento por eles encampado. Mas os anos 1980 já sinalizavam a lenta abertura política, evidenciada pelas diversas produções artísticas em que a denúncia e o rechaço ao autoritarismo de estado estavam bem evidentes, outros eventos tiveram um importante papel na construção da Democracia Corinthiana, como a greve do $\mathrm{ABC}$, de 1978, recuperada no filme como uma das evidências de que politicamente a ditadura já se encontrava em transição para uma forma de democracia, ainda que marcada por um forte conservadorismo, que não seria nenhuma novidade em se tratando do Brasil.

A explosão do rock nacional aliada à dinâmica de um novo cenário nos anos 1980, marcado pela invasão da música eletrônica das discotecas e dos videoclipes, promove o desenvolvimento do desejo de fazer uma cena musical em português

${ }^{15}$ ASBEG. Democracia em preto e branco, 1'11"-1'34". 
para o rock Nessa época, bandas como Joelho de Porco, Resto de Nada, AI-5, Condutores de Cadáveres, Detrito Federal e Aborto Elétrico criam a cena do punk rock nacional, inspirado no movimento inglês. Nos álbuns dessas bandas já podíamos observar as críticas, o sarcasmo e o humor em relação aos problemas sociais brasileiros, tais como a poluição, a fome, o desemprego e a miséria, expressas pelos nomes das bandas e pelas letras das músicas, fundamentalmente libertárias.

Concomitante ao punk rock, vemos o desenvolvimento de uma cena pop, tendo como um dos primeiros destaques da nova cena musical, preocupado em trazer fortes críticas à situação do país, nomes como Rita Lee, que juntamente com Roberto de Carvalho emplacam sucessos com letras que expressam o desejo de liberdade, seja no campo amoroso ou sexual, seja no campo das questões sociais. Hits como "Lança perfume”, “Baila comigo", “Nem luxo, nem lixo" e “Ôrra meu!” vão tomar conta das rádios brasileiras, até que em 1982, já sobre os anseios do movimento das Diretas Já!, ela emplaca a canção "Vote em mim”, a qual destaca sua intensa crítica feminista e política:

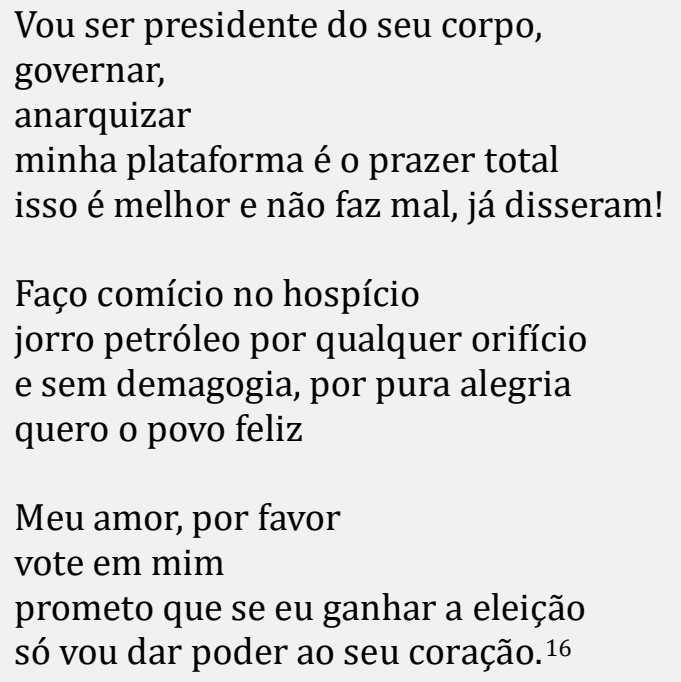

As três estrofes da canção deixam bem evidente o atrelamento ao projeto estético da cantora, na busca por debater aspectos ligados à liberdade sexual feminina, quando se refere ao "prazer total", mas o texto ultrapassa seu projeto estético, pois se articula especialmente com o momento político, já que a sociedade naquele momento não podia votar em presidente, mesmo havendo um importante

${ }^{16}$ RITA LEE. Vote em mim, 1982. 
movimento que buscava as eleições diretas para presidente. Daí a reflexão da necessidade de eleger e ser eleita presidente de um corpo, mesmo que para isso seja necessário "anarquizar".

Por falar em anarquia, o filme também faz essa articulação entre o rock e a rebeldia, como destaca o depoimento de Casagrande:

Todo dia eu tinha uma contestação, todo dia eu tinha uma polêmica, o motor era obrigado a ficar funcionando! Não era só gostar de rock, era ser livre, você viver a vida, era você contestar. 0 rock and roll, significa isso! Esse cara é rock and roll? Esse cara é louco... esse cara era vagabundo... esse cara é contestador... é rebelde! 17

Por isso Rita Lee, considera em sua música que para "ganhar a eleição" é preciso se mobilizar, por isso, "faço comício", para que tenhamos um "povo feliz". Esse é o cenário do Show do Ibirapuera, mostrando a importante relação de Rita Lee com o momento político que vivíamos no Brasil nos anos de 1980. 0 filme Democracia em preto e branco recupera algumas imagens desse período e corretamente convida Rita Lee para ser a voz off do filme que narra a história de paixão e desilusão da Democracia Corinthiana.

Apesar de boa parte das bandas terem surgido no início de 1980, só com o processo de redemocratização é que os jovens músicos daquela época vão se destacar em bandas como Barão Vermelho, Titãs, Os Paralamas do Sucesso, Legião Urbana, Engenheiros do Havaí, entre outras. No geral, o rock and roll da Democracia Corinthiana era internacional com bandas como AC/DC, Abba, Aerosmith, A-Ha, Bee Gees, Duran Duran, Guns'n Roses, Iron Maiden, Kiss, Led Zeppelin, Metallica, Nirvana, Pantera, Pink Floyd, Queen, Ramones, Sex Pistols, Santana, Scorpions, Simply Red, The Police, entre outras, mas já começava a ter os primeiros sons em português, que ainda com pouca evidência da mídia também compunham a cena musical desses anos de sussurros, com uma espécie de assovios à beira das quatro linhas.

Após a primeira metade da década de 1980, o rock nacional se fortaleceu com composições, que denunciavam a necessidade de mudança no aspecto político, com críticas diretas e, algumas vezes, despretensiosas falando dos romances e os

${ }^{17}$ ASBEG. Democracia em preto e branco, 21'52"-22'22". 
amores necessários, depois de quase duas décadas de repressão. Na ebulição do movimento político, músicas como “Inútil” (1985), da banda Ultraje a Rigor, teciam as cores cômico-sarcásticas do protesto de jovens de classe média, de uma geração apelidada de Coca-Cola ${ }^{18}$ como será apresentada à sociedade:
A gente não sabemos
Escolher presidente
A gente não sabemos
Tomar conta da gente
A gente não sabemos
Nem escovar os dente
Tem gringo pensando
Que nóis é indigente
"Inúteu"!
A gente somos "inúteu"!
"Inúteu"!
A gente somos "inúteu"!19

A juventude, classe média, tenta mostrar os contrastes brasileiros, por muito tempo escondidos pelo regime ditatorial, que anunciava sua força ligada ao "milagre econômico", que desenvolveu o Brasil, mesmo que fosse à custa da exploração dos trabalhadores e a entrega das reservas naturais para o capital estrangeiro, como destaca o II Plano Nacional de Desenvolvimento (PND) de setembro de 1974:

É necessário que a Agricultura e a Pecuária passem a desempenhar novo papel na estratégia nacional de desenvolvimento.

(...) A manter-se do quadro recente, poderia a agricultura continuar o crescimento geral, através do fornecimento dos alimentos e matériasprimas necessários, sem elevação do preço real (...).

Trata-se, agora, de exigir muito mais do setor agropecuário.

(...) A ocupação de novas áreas deverá continuar, como processo importante de expansão da agricultura, dada a existência de terras relativamente férteis para deslocamento da fronteira agrícola, e tendo

\footnotetext{
${ }^{18}$ Referência à música da banda Legião Urbana "Geração Coca-Cola", de 1985, que aponta para uma sociedade voltada ao consumismo capitalista, em especial aos produtos norteamericanos como as séries norte-americanas, que tomaram conta da televisão brasileira, os produtos industrializados, como os refrigerantes e as redes fast food. Uma geração de jovens educados em uma sociedade autoritária e ditatorial busca no consumo a liberdade das proibições dos vinte anos de ditadura, por isso, "filhos da revolução", "burgueses da nação" e "o futuro da nação", mesmos de forma sarcástica.

${ }^{19}$ ULTRAJE A RIGOR. Inútil, 1985.
} 
em vista que o gigantesco sistema viário já construído colocou à disposição do setor imensas áreas no Centro-Oeste e na Amazônia.

Por outro lado, o extraordinário dinamismo do setor não agrícola da economia, em anos recentes, criou as condições para tornar viável a modernização agrícola progressiva nas áreas já ocupadas.

(...) A atual dimensão do setor não agrícola já é suficiente para apoiar a modernização produtiva da agricultura do Centro-Sul.

Ao mesmo tempo, passando a agricultura a servir de modo mais eficaz à estratégia, à elevação mais rápida de sua renda líquida ajudará a manter o alto dinamismo do resto da economia (através da demanda por insumos e por bens de consumo), além de contribuir de forma mais significativa para a redução do déficit na balança de comércio. ${ }^{20}$

Esse documento deixa bem claro qual é a estratégia da ditadura com o seu projeto desenvolvimentista, que inclui o incentivo e financiamento de duas fronteiras agropecuárias, uma na Amazônia e outra no Pantanal, biomas que deveriam ser preservados pelo estado brasileiro, mas que foram alvo de um ambicioso projeto de devastação das florestas. Sabemos, entretanto, que esse projeto iniciou com outra ditadura, a de Vargas, mas se concretizou muito bem na de 1964. E hoje, nos sobram só os rumores da necessidade de salvar a Amazônia e o Pantanal, que sofrem até hoje com a desmedida dos projetos ditatoriais para as regiões, que continuam pobres e intensamente exploradas, por suas riquezas e extensas dimensões territoriais, mas as coisas não devem mudar, pois o atual presidente do Brasil reforça o projeto ditatorial, asseverando que "A Amazônia tem que ser explorada, não abro mão disso!".21

A exploração e a violência que o estado ditatorial impôs à sociedade brasileira será uma das problemáticas mais evidenciadas pelas bandas do rock 80 , como forma de mostrar que a rebeldia do rock mantém a sua disposição à denúncia, mesmo depois do fim oficioso da ditadura, em 21 de abril de 1985, data da posse do primeiro presidente eleito. Um presidente eleito de forma indireta, não militar, ironicamente após 21 anos (e 21 dias) de ditadura (1964-1985), cuja posse é festejada junto com a comemoração de um mártir da independência, Tiradentes, forjado para ser esquecido. Pensamos que talvez tenha sido essa a intenção da ditadura: fazer dessa posse algo esquecível, uma vez que no contexto dos encaminhamentos e estratégias da Abertura a ditadura mantém o seu legado,

\footnotetext{
${ }^{20}$ BRASIL. Plano Nacional de Desenvolvimento, p. 41-42.

${ }^{21}$ MOREIRA. O Globo, 21/10/2019.
} 
marcado com a presença dos mesmos ranços do autoritarismo militar. A título de exemplo, temos um grande sucesso de 1986, "Estado violência", da banda Titãs, nele seu texto evidência a hipocrisia de um estado "democrático", que mantém suas práticas autoritárias, como se ainda estivéssemos na ditadura. Mas, será que não estávamos?! Vejamos:

\author{
Sinto no meu corpo \\ A dor que angustia \\ A lei ao meu redor \\ A lei que eu não queria. \\ Estado violência \\ Estado hipocrisia \\ A lei que não é minha \\ A lei que eu não queria. \\ Meu corpo não é meu \\ Meu coração é teu \\ Atrás de portas frias \\ O homem está só. \\ Homem em silêncio \\ Homem na prisão \\ Homem no escuro \\ Futuro da nação. \\ Estado violência \\ Deixem-me querer \\ Estado violência \\ Deixem-me pensar. \\ Estado violência \\ Deixem-me sentir \\ Estado violência \\ Deixem-me em paz. ${ }^{22}$
}

$\mathrm{Na}$ esteira de "Estado violência", víamos surgir inúmeras outras músicas com esse mesmo teor crítico denunciando a política de violência do estado brasileiro, o aumento alarmante da população carcerária e a falta de perspectiva dos homens no escuro, o que impossibilita termos um futuro para a nação, já que o estado não deixa o povo querer, pensar e sentir. 0 álbum se chamava Cabeça Dinossauro, uma alusão aos antagonismos de uma sociedade que se dizia

${ }^{22}$ TITÃS. Estado Violência, 1986. 
democrática, mas ainda com práticas de um mundo primitivo e absurdamente predador, alusões presentes na capa do álbum, reproduzida abaixo.

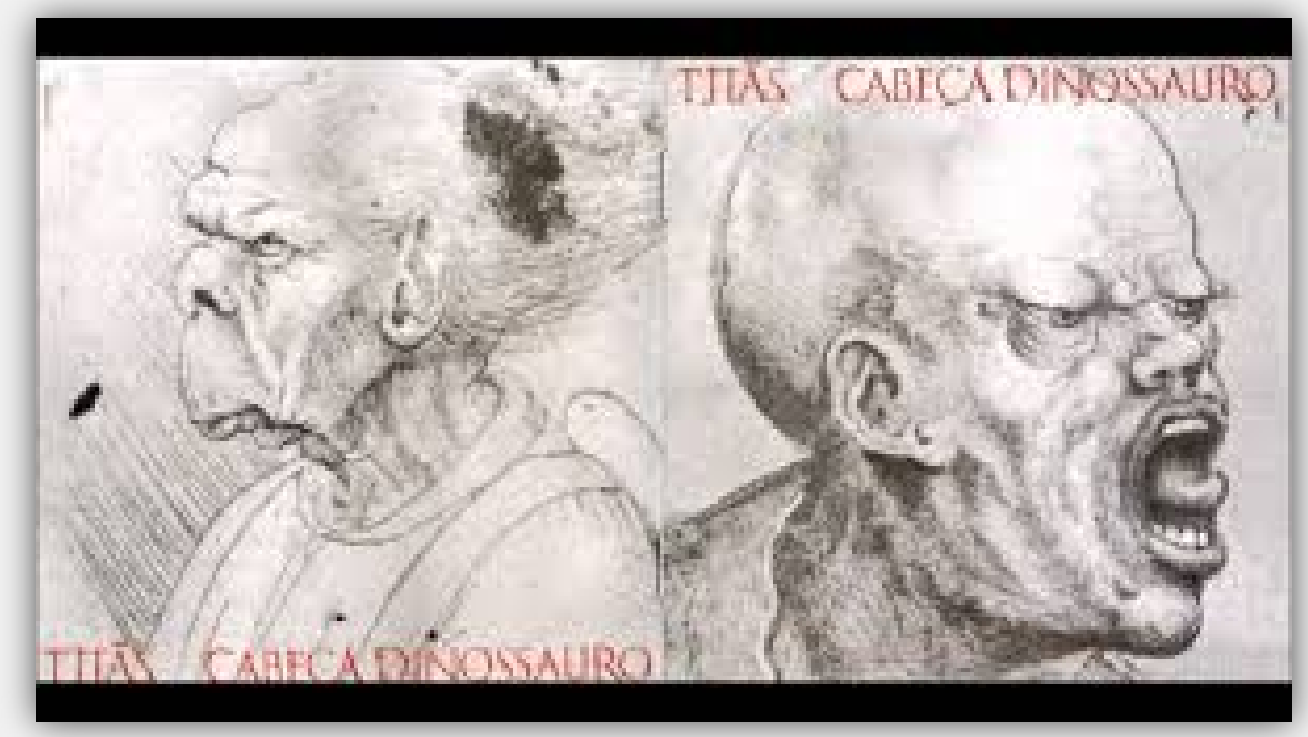

Imagem 1: Capa do álbum Cabeça Dinossauro, 1986, Titãs.

A deformidade e a alusão aos primatas revelam a deformidade da sociedade brasileira, mesmo depois da ditadura e da "evolução". Outras músicas deste álbum também faziam fortes críticas ao autoritarismo, como "Bichos escrotos", "Homem primata", "AA UU" e "Polícia", esta última retoma o confronto contra a violência de estado na figura da polícia, quando "dizem que ela existe para ajudar/ dizem que ela existe para proteger/ eu sei que ela pode te parar/ eu sei que ela pode te prender". ${ }^{23} 0$ verbo aqui associa o texto da música às incertezas do verdadeiro papel da polícia, a proteção.

Ao ouvirmos as canções dos anos 1980 temos a sensação de que aqueles tempos não ficaram no passado e que os paradigmas da polícia e da política, que nutriram o Brasil nesse período, continuam plenamente presentes nas primeiras décadas do Século XXI. Um bom exemplo dessas continuidades é o conturbado episódio ocorrido na Câmara dos Deputados, em Brasília, na sequência da abertura da exposição “Trajetórias Negras”, em 19/11/2019, quando vimos nos ecrãs, divulgadas por todas as mídias, notícias sobre a agressão de um deputado federal e coronel da polícia, à obra do cartunista Carlos Latuff, uma clara expressão da

${ }^{23}$ TITÃS. Polícia, 1986. 
manutenção da arrogância e truculência, tão próprias das bases autoritárias, ainda perdurando e repercutindo na atualidade. Ao rasgar e jogar no chão uma das peças da exposição, o coronel e deputado, justificou sua ação asseverando que "o cartaz era nitidamente uma ofensa aos policiais do país". ${ }^{24}$

0 material compunha uma exposição pensada em debater problemas vivenciados pela sociedade em alusão ao mês da consciência negra, o cartaz destruído versava sobre o genocídio das populações negras. A agressão gerou denúncia no conselho de ética por racismo, já que se tratava de um material ligado às comemorações pelo dia da consciência negra, mas entendemos que o problema não se restringe às questões raciais, a ação do parlamentar vai ao encontro das denúncias presentes na música dos Titãs e no filme Democracia em preto e branco, pois a agressão na Câmara é contra a democracia, o direito de expressar o sofrimento das populações subalternizadas, que, ainda hoje, estão sendo exterminadas pelo braço armado do estado brasileiro, com dados comprovativos, veiculados pelo IPEA (Instituto de Pesquisas Econômicas) e utilizados no cartaz exposto no Hall da Taquigrafia da Câmara. Abaixo, reproduzimos a charge que foi objeto da ira do deputado federal e coronel da polícia:

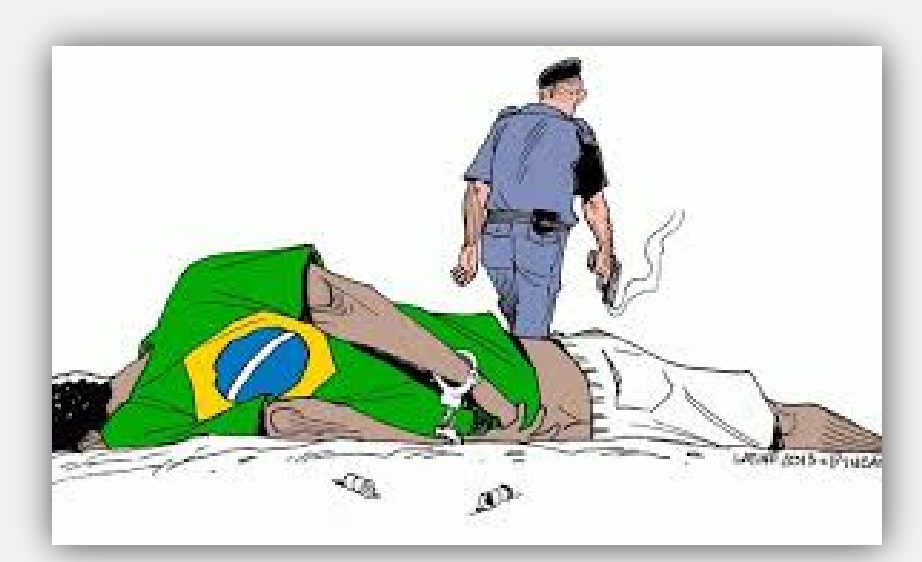

Imagem 2: Charge Latuff, "o genocídio da população negra”.

Fica evidente a relação crítica entre o conteúdo da charge e as mortes criminosas por parte da polícia, uma vez que há um jovem negro, algemado antes de ser morto, há projéteis utilizados ao chão, elementos que demonstram a execução pelo policial que, na certeza da impunidade, dá as costas ao cadáver e ao resto da

\footnotetext{
${ }^{24}$ BOLDRINI. Deputado do PSL quebra peça de exposição sobre Consciência Negra na câmara, p. 1.
} 
nação, representada pela camisa que veste o corpo inerte. A charge, dessa forma, questiona: a polícia é para proteger, mas a quem?

Os Titãs terminam o álbum Cabeça dinossauro com o ourobórico 25 "O quê", uma música que fixa nossos ouvidos à perplexidade da realidade violenta dos anos posteriores à ditadura, com o grito "Que não é o que não pode ser", ${ }^{26}$ uma espécie de poema processo interminável, como a reflexão da infinitude e os conflitos do ciclo da vida e da morte, como o icônico O grito (Skirk), de Edward Munch. Na música, nos parece que o juiz usou o VAR para saber se foi pênalti ou quem é o cara da jogada.

No mesmo caminho, o filme nos apresenta outra música bastante icônica desse período, "Selvagem", a qual destaca também o valoroso trabalho da polícia na repressão da sociedade, música lançada em 1986, pela banda Os Paralamas do Sucesso, revela o quanto a liberdade e a democracia também não passam de falácias:

\author{
A polícia apresenta suas armas \\ Escudos transparentes, cassetetes \\ Capacetes reluzentes \\ $\mathrm{E}$ a determinação de manter tudo \\ Em seu lugar \\ 0 governo apresenta suas armas \\ Discurso reticente, novidade inconsistente \\ E a liberdade cai por terra \\ Aos pés de um filme de Godard \\ A cidade apresenta suas armas \\ Meninos nos sinais, mendigos pelos cantos \\ E o espanto está nos olhos de quem vê \\ 0 grande monstro a se criar \\ Os negros apresentam suas armas \\ As costas marcadas, as mãos calejadas \\ E a esperteza que só tem quem tá \\ Cansado de apanhar. ${ }^{27}$
}

\footnotetext{
${ }^{25}$ Refere-se à imagem do ouroboros ou oroboro, reconhecida figura mítica, que na cultura grega significa "devorador de cauda", por conta da junção de oura (cauda) e boros (comer). Imageticamente temos um círculo, quando uma serpente engole sua própria cauda e está relacionado a uma complexa reflexão sobre o ciclo da vida, a qual carrega os sentidos de junção do início ao fim, o infinito, a mudança, o tempo, a evolução, a fecundação, o nascimento, a morte, a ressurreição, a criação, a destruição, a renovação.

${ }^{26}$ TITÃS. O quê?, 1986.

${ }^{27}$ OS PARALAMAS DO SUCESSO. Selvagem, 1986.
} 
De forma comovente, temos uma reflexão d'Os Paralamas em relação à própria condição negra e o genocídio que já se percebia presente em 1986, pois no final da canção há uma refutação em relação à violência praticada contra o negro, depois de quase 100 anos da abolição da escravatura (13/05/1888).

0 filme traz ainda outras referências ao debate em relação ao papel do negro na sociedade, em especial, a importante figura de Wladimir Rodrigues dos Santos, o principal formador político do movimento, inclusive de Sócrates, considerado a imagem viva da Democracia Corinthiana, como vemos na passagem a seguir. $\mathrm{Na}$ sequência temos respectivamente a narração de Rita Lee e o testemunho de José Paulo Florenzano:

A formação política do Doutor Sócrates começou com as ideias que vinham da esquerda. Na lateral do timão Wladimir Rodrigues dos Santos foi dos primeiros jogadores brasileiros a se ver como operário da bola e a perceber nas greves do $\mathrm{ABC}$, a força que a organização sindical trazia a classe trabalhadora.

É extremamente importante resgatar o papel do Wladimir, porque o Wladimir desempenha um papel chave na própria transformação do Sócrates. Essa relação de Amizade com o Wladimir é decisiva, porque o Wladimir então desse processo de conscientização do atleta brasileiro, já tinha uma história. ${ }^{28}$

Fica evidente o papel político de Wladimir e o filme resgata sua importância apesar de se centrar muito pouco na relação do jogador com sua atuação como sindicalista e a importância por ser negro, articulado a todo o preconceito que existe no Brasil, que ainda hoje é bastante velado, como no episódio do deputado contra a charge de Carlos Latuff.

O próprio Wladimir analisa como era incômodo o momento histórico da época. Ele comenta: "sempre fui inconformado com essa situação. A gente ficava incomodado com o fato de não poder interferir nas decisões do país. Então isso me levou a ser líder sindical". ${ }^{29} 0$ documentário utiliza uma entrevista de Wladimir a uma emissora de TV, que lhe questiona sobre sua identidade ou identificação com Zumbi dos Palmares, o qual responde: "Acho que o fato dele lutar constantemente, enquanto viveu, pela libertação da raça negra".30

\footnotetext{
${ }^{28}$ ASBEG. Democracia em preto e branco, 18'04"-18'50".

29 ASBEG. Democracia em preto e branco, 18'56"-19'17".

30 ASBEG. Democracia em preto e branco, 19'31"-19'40".
} 
Neste caso a libertação da raça está ligada aos estereótipos que circundam o homem negro, que mesmo não estando envolvido com o crime, continuar a ser encarado como culpado, pelo fato de ser negro. No futebol, sabemos que mesmo tendo grandes jogadores, ídolos nacionais, como Garrincha e Pelé, não seria fácil ganhar protagonismo em um esporte extremamente elitista, que nasce nas mãos dos brancos e aos poucos vai se matizando, mas sem deixar de lado o ranço elitista, que infelizmente ainda promove cenas deploráveis decorrentes de preconceito, quando torcedores xingam atletas por conta da etnia ou da opção sexual.

A crítica central desse estudo perpassa pelo fato de que mesmo quando temos um documentário que admite a importância política de um negro no futebol, ainda assim, ele não ganha o espaço necessário para debater tal questão. Daí dizer que tanto movimento Democracia Corinthiana, quanto o filme são mais brancos do que pretos.

Sabemos da necessidade de valorizar a disposição em narrar a história a contrapelo, como nos ensina Walter Benjamim, já que "na luta de classes essas coisas espirituais não podem ser representadas com despojos atribuídos ao vencedor. Elas se manifestam nessa luta sob a forma de confiança, da coragem, do humor, da astúcia, da firmeza, e agem de longe do fundo dos tempos". ${ }^{11}$ Mas não podemos deixar de lado que o filme não consegue dar a devida importância a Wladimir, como sendo o principal articulador político da Democracia Corinthiana, uma vez que o foco dos debates ainda se fixa nas figuras do doutor Sócrates, e na jovem promessa rock and roll associada ao descolado Casagrande: são os brancos que ganham o protagonismo no filme, mesmo Sócrates admitindo a importância de Wladimir para o movimento:

O Wla é talvez o braço mais forte do processo. Primeiro pela história dele, fisicamente ligado ao Corinthians, segundo, é negro! Isso tem um peso fundamental por tudo que a gente viveu. Em um país tão racista quanto o nosso, cuja cor de pele é sinônimo de riqueza ou pobreza. É fundamental que temos alguém que represente a maior parte da nação. ${ }^{32}$

Muito louvável a disposição de Sócrates em considerar Wladimir o braço forte da democracia, mas como espectadores sentimos falta de um maior espaço

\footnotetext{
${ }^{31}$ BENJAMIM. Sobre o conceito de história, p. 224.

32 ASBEG. Democracia em preto e branco, 19'40"-20'11".
} 
para a matéria, pois foram despendidos apenas dois minutos, dos noventa, para falar do lateral esquerdo e sindicalista do Parque São Jorge.

0 mesmo ocorre em relação à articulação do rock and roll ao movimento da democracia, pois as músicas escolhidas para essa articulação foram lançadas muito tempo depois do fim do movimento político-desportivo, o que passa uma falsa impressão de que ocorreram concomitantemente. Fora isso, vemos que o filme dá conta do que se propôs, já que faz um passeio pela história da Democracia Corinthiana, acentuando diversas ligações entre o movimento, o sindicalismo, a política nacional e necessidade de mudança nos rumos do país e do clube. Mas, nem tudo foi uma maravilha, pelo contrário, o resultado do jogo acabou com a derrota tanto do Brasil, pois não conseguiu a aprovação das eleições diretas, quanto do Corinthians, que não conseguiu ser campeão brasileiro, mesmo dando grande passo para o reconhecimento do clube como um dos mais populares do Brasil.

No último giro dos ponteiros, vimos que a democracia prenunciada durou muito pouco e não conseguiu se firmar, mas deixou para nós um exemplo de que é possível fazer grandes revoluções mesmo diante de tantas pressões e uma história brasileira focada em uma realidade mais branca do que preta, em que o autoritarismo está impregnado, inclusive nas quatro linhas. Fim de papo!

\section{REFERÊNCIAS}

ADORNO, Theodor. Teoria Estética. Tradução: Artur de Mourão, Lisboa: Edições 70, 1993.

BENJAMIN, Walter. Sobre o conceito de história Magia e técnica, arte e política: ensaios sobre literatura e história da cultura. Tradução: Sergio Paulo Rouanet, $7^{\mathrm{a}}$ ed., São Paulo: Brasiliense, 1994.

BOBBIO, Norberto; MATTEUCCI, Nicola; PASQUINO, Gianfranco. Dicionário de Política. Brasília: Editora Universidade de Brasília, $1^{\mathrm{a}}$ ed., 1998.

BOSI, Alfredo. Narrativa e resistência. Revista Itinerários. Araraquara: UNESP, n. 10, 1996. 
BOLDRINI, Ângela. Deputado do PSL quebra peça de exposição sobre Consciência Negra na câmara: charge retratava jovem morto por policial e foi considerada ofensiva pela 'bancada da bala'. Folha de São Paulo, 19/11/2019 p. 1. Disponível em: https://bit.ly/2N5xufT. Acesso em: 21 de nov. de 2019.

BRASIL, República Federativa do Brasil. Projeto do II Plano Nacional de Desenvolvimento II PND (1975-1979), Brasília, 1974, p. 41-42. Disponível em: www.biblioteca.presidencia.gov.br > catalogo > geisel > ii-pnd-75_79.

CORNELSEN, Elcio. Sentimento e política no futebol alemão: construção da nação em 1990 e 2006. História: Questões \& Debates, Curitiba, n. 57, p. 7399, jul.-dez. 2012.

LATUFF, Carlos. Charge: O genocídio da população negra, 2013. Disponível em: https://bit.ly/35CCvTG. Acesso em: 22 nov. 2019.

MOREIRA, Assis. "A Amazônia tem que ser explorada, não abro mão disso", afirma Bolsonaro em Tóquio. O Globo, 21 out. 2019. Caderno Sociedade. Disponível em: https://glo.bo/2T3cjyG. Acesso em: 01 nov. 2019.

\section{FILMOGRAFIA}

ASBEG, Pedro (direção). Democracia em preto e branco. Brasil, son., color., 2014, 63 min.

\section{DiscograFIA}

IRA! Núcleo Base. Mudança de comportamento. Produção: Pena Schmidt. Rio de Janeiro: WEA, 1985.

OS PARALAMAS DO SUCESSO. Selvagem. Selvagem?. Produção: Liminha. Rio de Janeiro: EMI, 1986.

RITA LEE. Amor branco e preto. Hoje é o primeiro dia do resto de sua vida. Produção: Arnaldo Baptista. Rio de Janeiro: Philips Records/Polydor Records, 1972.

RITA LEE. Vote em mim. Rita Lee e Roberto de Carvalho. Produção: Rita Lee, Roberto de Carvalho e Max Pierre. Rio de Janeiro: Som Livre, 1982.

TITÃS. O quê?; Polícia; Estado violência. Cabeça Dinossauro. Produtores: Liminha, Vitor Farias e Pena Schmidt, Rio de Janeiro: WEA, 1986.

ULTRAJE A RIGOR. Inútil. Nós vamos invadir a sua praia. Produção: Liminha e Pena Schmidt, Rio de Janeiro: WEA, 1985. 